\title{
KAJIAN ILMU FALAK DI INDONESIA: Kontribusi Syekh Hasan Maksum dalam Bidang Ilmu Falak
}

\author{
Arwin Juli Rakhmadi Butar-Butar \\ Universitas Muhammadiyah Sumatera Utara, Indonesia \\ Jl. Kapten Mucthar Basri No. 108-112, Sumatera Utara \\ e-mail: arwin_buntupane@yahoo.co.uk
}

\begin{abstract}
The Study of Astronomy in Indonesia: Shaykh Hasan Maksum's Contribution to Astronomy. Islamic scholars have played a role for the strengthening and preservation of Islamic scholarship in Indonesia, including in Astronomy. Unfortunately, works on this field have not been studied accordingly. This article examines the contribution of Shaykh Hasan Maksum, a very influential mufti on Deli Sultanate in East Sumatra. Like many other Nusantara scholars, he studied in Haramain (Makkah and Madinah) for a substantial time. This article studies his work, Natîjah Abadiyah, applying Content Analysis. It is clear that the Natijah Abadiyah is a short yet very important for it contains daily prayer timetable and some necessary explanations.
\end{abstract}

Keywords: Indonesia, East Sumatera, Astronomy, Hasan Maksum 


\section{Pendahuluan}

Syekh Hasan Maksum adalah tokoh ulama kharismatik di zamannya, khususnya di Sumatera Timur ${ }^{1}$ (sekarang Sumatera Utara). Bahkan kepopulerannya, khususnya di kota Medan, masih terasa sampai hari ini. Ketokohannya tampak dari posisinya sebagai Mufti Kesultanan Deli waktu itu yang menjadikannya sangat disegani dan dihormati masyarakat. Masjid Raya al-Mashun, masjid kebanggaan di kota Medan hingga saat ini, agaknya tidak dapat dipisahkan dari sosok Syekh Hasan Maksum. Masjid peninggalan Kerajaan Sultan Deli yang telah berusia 100 tahun lebih ini menjadi salah satu bukti kepiawaian Syekh Hasan Maksum dalam bidang ilmu falak (astronomi) khususnya dalam hal penentuan arah kiblat dan waktu salat. Masjid ini mulai dibangun pada tahun $1906 \mathrm{M}$ dan selesai tahun 1909 M. Peletakan batu pertama dilakukan oleh Sultan Ma'mun al-Rasyid Perkasa Alamsyah IX. Beberapa bahan dekorasi masjid ini didatangkan dari Italia dan Jerman yang menunjukkan keseriusan para pendirinya. Masjid ini juga merupakan satu kesatuan dengan komplek istana.

Seperti diketahui, akurasi arah kiblat masjid ini sangat akurat dimana telah dilakukan penelitian atasnya oleh sejumlah peneliti di era modern. Tidak ada informasi persis yang menyatakan bahwa Syekh Hasan Maksum adalah orang yang menentukan arah kiblat masjid ini. Tetapi dengan keberadaannya di masjid ini sebagai tokoh ulama yang mengajarkan ilmu-ilmu agama, diduga kuat bahwa ia mengetahui akurasi arah kiblat masjid ini secara baik, bahkan boleh jadi ia pernah mengakurasi ulang arah kiblat masjid ini. Demikian lagi seperti tampak dalam salah satu karyanya yang berjudul Natîjah Abadiyah menunjukkan bahwa Syekh Hasan Maksum memiliki telaah dan kontribusi dalam hal penentuan waktu-waktu salat yaitu berupa jadwal (natijah) waktu salat abadi. Jadwal waktu salat abadi ini mustahil dapat disusun jika tidak menguasai konsep umum tentang penentuan 
waktu-waktu salat yaitu terkait pemahaman terbit, terbenam, fajar, zawal, ketinggian, dan deklinasi. Dalam perkembangannya jadwal waktu salat abadi yang ia susun ini digunakan di sejumlah masjid di kota Medan bahkan sampai hari ini.

Dari dua keahlian dan kepiawaiannya ini, bisa dikatakan bahwa Syekh Hasan Maksum memiliki kualitas dan kemampuan di bidang ilmu falak. Kepiawaiannya ini sendiri diduga berasal dari ketika ia belajar di Timur Tengah. Seperti halnya ulamaulama Nusantara lainnya, ia juga pernah belajar di Haramain (Makkah-Madinah) dalam waktu yang cukup lama. Seperti tampak lagi dari karya-karyanya, selain menulis karya di bidang fikih, akidah, dan tasawuf, Syekh Hasan Maksum juga memiliki satu karya dan telaah khusus di bidang ilmu falak berjudul Natîjah Abadiyah (Natijah Abadi). Buku ini memang teramat ringkas yang berisi daftar dan penjelasan tentang waktu-waktu salat abadi dimana dalam beberapa waktu, jadwal waktu salat abadi ini digunakan dan menjadi panduan umat Muslim di Sumatera Utara. Dengan karya dan pemikirannya di bidang waktu salat (abadi) dan arah kiblat ini, dapat dinyatakan bahwa Syekh Hasan Maksum adalah tokoh ulama Nusantara yang berperan dalam historiografi dan peta transmisi perkembangan ilmu falak di Nusantara.

\section{Metode Penelitian}

Artikel ini mengkaji kontribusi Syekh Hasan Maksum dalam bidang ilmu falak. Secara khusus, akan dikaji biografinya, kontribusinya dalam bidang ilmu falak, dan kitabnya yang berjudul Natîjah Abadiyah. Kajian ini bisa dikatakan baru karena belum ada yang mengkajinya secara khusus. ${ }^{2}$ Metode kajian ini adalah analisis isi, dimana sumber utamanya adalah karya-karya Syekh Hasan Maksum. 


\section{Hasil dan Pembahasan Biografi Syekh Hasan Maksum}

Syekh Hasan Maksum lahir di Labuhan Deli (Sumatera Timur) tahun $1302 \mathrm{H} / 1884 \mathrm{M}^{3}$, dan wafat pada hari Kamis, 24 Syawal 1355 H/1937 M, pada usia 53 tahun. Ayahnya (H. Maksum, Datuk Bandar) adalah orang yang berada, disegani, dan memiliki tanah yang luas. ${ }^{4}$ Sejak kecil Syekh Hasan Maksum memang telah tampak memiliki bakat dan kecerdasan serta memiliki kecenderungan kepada ilmu. Ia mudah menangkap dan menghapal ilmu yang dipelajari.

Menjelang usia 10 tahun, Hasan Maksum dianjurkan untuk melanjutkan studi pada sekolah Inggris, namun ia memilih menuntut ilmu ke Makkah yang merupakan anjuran ayahnya. Pada tahun $1894 \mathrm{M}$ (saat usia 10 tahun), ia bersama rombongan jamaah lainnya pergi menunaikan haji dengan naik kapal laut dengan terlebih dahulu singgah di Singapura. Kepergiannya diiringi dengan ratap tangis dari keluarga, karena kepergiannya diperkirakan dalam waktu yang lama serta tidak ada jaminan akan kembali. ${ }^{5}$

Di Makkah, Hasan Maksum bertemu Syekh Ahmad Khatib Minangkabau yang waktu itu telah menjadi guru dan mufti di Makkah. Bahkan Syekh Ahmad Khatib sangat memercayai Hasan Maksum, karena kecerdasan dan akhlaknya. ${ }^{6}$ Selain itu, Syekh Hasan Maksum juga belajar kepada H. Abdussalam (yang berasal dari Kampar dan guru kenamaan di Makkah). Ia juga belajar kepada Muhammad Khayyath (seorang ulama ternama di Makkah), dari ulama ini dia belajar tasawuf. Dari Syekh Abdul Malik, ia belajar ilmu Nahwu. Sedangkan dari Syekh Ahmad Khatib, ia belajar fikih. Di Madinah, ia juga belajar kepada Syekh Amin Ridwan (berasal dari Minangkabau). ${ }^{7}$ 
Hasan Maksum belajar di Makkah selama 9 tahun. Setelah itu ia kembali bersama rombongan jamaah haji melalui Singapura, lalu ke Labuhan (Medan). Beberapa waktu kemudian, ia kembali lagi ke Makkah guna menuntut ilmu selama 3 tahun. Setelah kembali lagi ke tanah air, ia menikah dan untuk kali yang ketiga kembali ke Makkah. Pada periode ini, Syekh Hasan Maksum telah populer di Makkah dan menjadi seorang ulama, dimana banyak murid-murid (terutama dari Nusantara) yang belajar kepadanya.

Setelah kembali lagi ke Nusantara, aktivitas Syekh Hasan Maksum diisi dengan mengajar. Tercatat ia pernah mengajar di Wilhelminastraat (di Jalan Japaris, tahun 1928 M). Selain itu, ia juga mengajar di Masjid Raya, Masjid Kesultanan Deli. Sultan Maimon Rasyid (Raja Kesultanan Deli waktu itu) menawarkan Syekh Hasan Maksum jabatan ulama kerajaan dengan maksud menjadi benteng agama di Tanah Deli. Pada awalnya, ia menolak dengan sejumlah alasan, namun akhirnya ia menerima amanah itu. Sejak saat itulah ia mendapat gelar Imam Paduka Tuan. Beberapa muridnya mendirikan organisasi Al Jam'iyatul Washliyah ${ }^{8}$ dan Al-Ittihadiyah. ${ }^{9}$

Syekh Hasan Maksum tercatat sejumlah karya, diantaranya ditulis tatkala masih berada di Makkah (antara tahun 1912 M1916 M). Adapun karya-karyanya yaitu: ${ }^{10}$ Samîr al-Shibyân (tentang fikih), Tanqîh al-Zhunûn (tentang tauhid), Targhîb al-Mustaqîm (tentang salat Jumat), Sharim al-Mumayyiz 'an Tala'ub bi Kalâm al-'Azîz (tentang akidah/tauhid), Natîjah Abadiyah (tentang waktu salat), Ittihâf al-Ikhwân (tentang wirid-wirid dan doa), Fath al-Wadûd (tentang niat salat), Tadzkîr al-Murîdîn Sulûk Tharîqah al-Muhtadîn (tentang tasawuf), al-Maqalah al-Nâfi' ah fîmâ Yata 'allaq bi Qabliyah al-Jum'ah (tentang qabliyah Jumat), Durar al-Bayân Syarh Hidâyah al-Ikhwân (tentang akidah/usuluddin), al-Quthufat al-Saniyyah li Man'Ba'dh mâ fî al-Fawâ'id al-'Âliyah 
(tentang dialektika kaum Tua-Muda), dan Is âf al-Murîdîn (tentang tasawuf).

\section{Kontribusi Syekh Hasan Maksum dalam Bidang Ilmu Falak}

Setidaknya ada dua kontribusi Syekh Hasan Maksum di bidang ilmu falak, yaitu jadwal waktu salat dan akurasi arah kiblat. Seperti dimaklumi, dua hal ini adalah kebutuhan harian umat Muslim dalam melaksanakan ibadah.

\section{Jadwal Waktu Salat}

Konsep Umum Waktu-Waktu Salat

Waktu-waktu salat pada dasarnya adalah menentukan posisi harian matahari. Rumusan ayat-ayat dan hadis-hadis mengenai waktu salat merupakan penerjemahan posisi harian matahari ini. Pergerakan matahari yang menjadi standar waktu salat merupakan perhatian umat Muslim sepanjang zaman. Dari pengamatan ini diketahui bahwa matahari setiap harinya bergerak dan bergeser dari posisinya. Menentukan posisi matahari di suatu hari dan di suatu tempat merupakan aspek astronomis utama dalam penentuan waktu-waktu salat. Karena itu mengetahui pergerakan matahari yang berubah-ubah sepanjang hari dan sepanjang tahun adalah hal yang teramat penting.

Beberapa data harian terpenting matahari terkait penentuan waktu-waktu salat adalah: ketinggian, kulminasi, terbit-terbenam, refraksi, kerendahan ufuk, paralaks, dan syafak. Ketinggian dan kulminasi berkaitan dengan penentuan waktu Zuhur dan Asar. Terbit, terbenam dan syafak terkait dengan penentuan waktu Subuh, Maghrib dan Isya. Sementara refraksi, kerendahan ufuk dan paralaks berfungsi sebagai koreksi dan akurasi bagi waktu- 
waktu salat secara keseluruhan. Berikut ini akan dijelaskan variabelvariabel tersebut dalam rumusan waktu-waktu salat. ${ }^{11}$

Waktu Zuhur dimulai ketika tepi piringan matahari telah keluar dari garis zenit atau ketika matahari meninggalkan meridian sesaat setelah matahari berkulminasi hingga panjang bayangbayang suatu benda lebih panjang dari obyek sebenarnya.

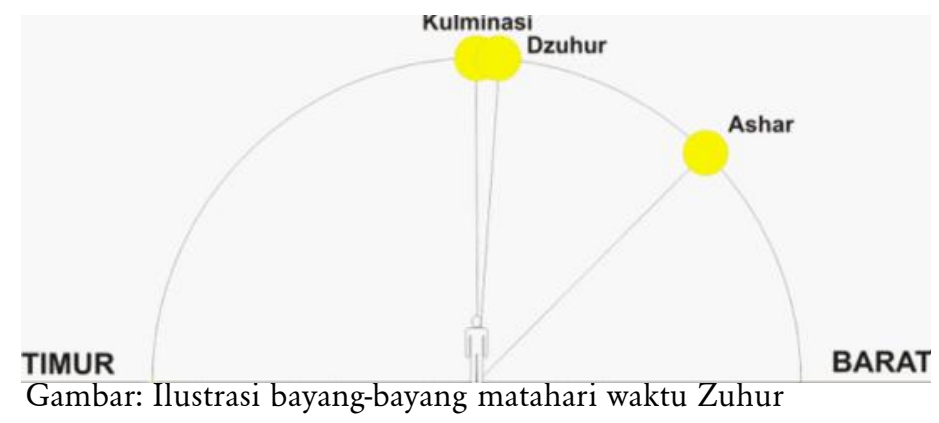

Mengenai waktu Asar, ada dua redaksi hadis Nabi Muhammad SAW. terkait hal ini. Redaksi pertama menyatakan ketika bayangbayang suatu benda seukuran bendanya. Redaksi kedua menyatakan ketika bayang-bayang suatu benda seukuran dua kali benda itu. Perbedaan dua redaksi ini mengakibatkan perbedaan penjabaran astronomis terhadap masa tibanya waktu Asar.

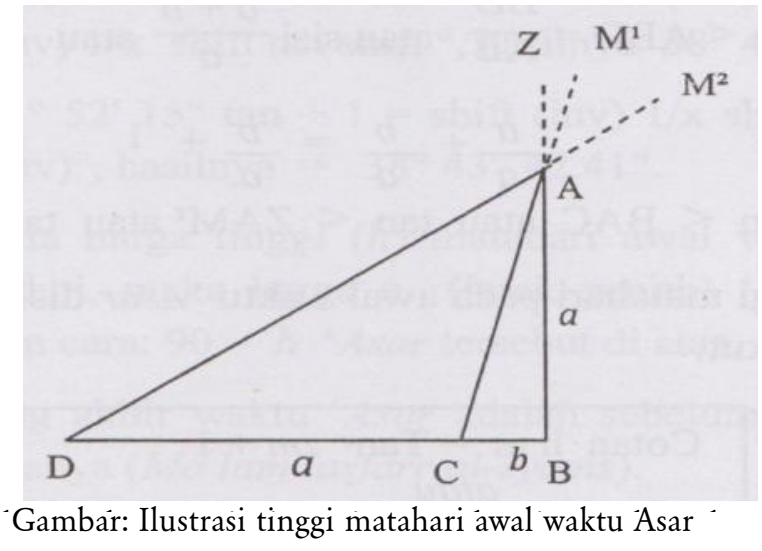


Waktu Maghrib adalah ketika matahari terbenam. Setidaknya ada dua pandangan mengenai terbenam. Pandangan pertama menyatakan apabila matahari telah mencapai ufuk. Pandangan kedua menyatakan apabila piringan matahari seluruhnya telah berada di bawah ufuk.

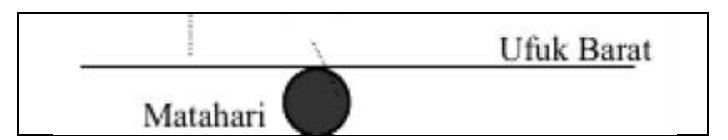

Gambar: Ilustrasi matahari terbenam (Maghrib)

Waktu Isya adalah tatkala langit tampak gelap karena cahaya matahari di bawah ufuk tidak dapat lagi dibiaskan oleh atmosfir. Waktu Isya ditandai dengan memudarnya cahaya merah di ufuk barat yaitu bila jarak zenit matahari $z=108$ derajat.

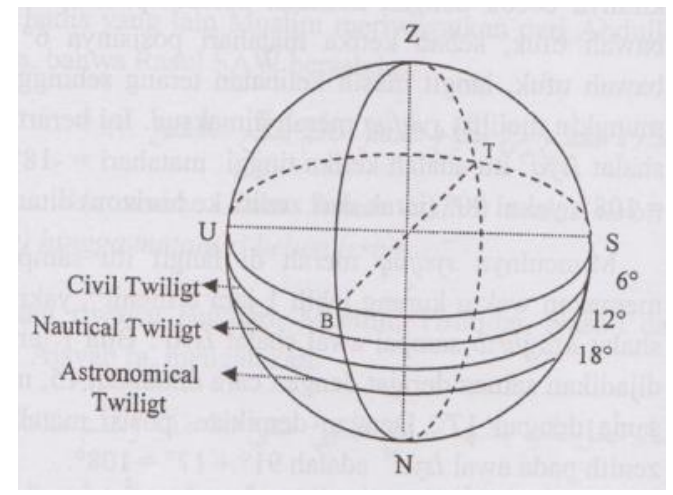

Gambar: Ilustrasi civil twilight, nautical twilight dan astronomical twilight

Sedangkan waktu Subuh adalah saat fajar menyingsing pagi hari, yaitu ketika langit tidak lagi gelap dimana atmosfir bumi mampu membiaskan cahaya matahari dari bawah ufuk. Berdasarkan keterangan hadis Nabi Muhammad SAW., waktu 
Subuh dimulai tatkala terbit fajar sadik. Menurut Husain Kamaluddin, berdasarkan penelitian, fajar sadik adalah ketika matahari terletak pada posisi 18 derajat di bawah ufuk (-18). ${ }^{12}$ Fajar sadik ini dalam astronomi disebut dengan astronomical twilight. ${ }^{13}$

\section{Waktu Salat Abadi}

Jadwal waktu salat Abadi disebut juga dengan jadwal waktu salat sepanjang masa. Penamaan demikian adalah karena jadwal waktu Salat tersebut dapat digunakan untuk selama-lamanya atau sepanjang waktu. Model-model jadwal waktu salat abadi sebagai berkembang di tengah masyarakat umumnya berupa jadwal pada satu lembar dengan ukuran besar, di dalamnya terdapat jadwal waktu Salat mulai dari bulan Januari sampai bulan Desember. Selanjutnya jadwal itu digunakan untuk sepanjang waktu (abadi). Selanjutnya pada jadwal itu tercantum nama tokoh yang menyusun (menghitung) jadwal waktu salat abadi itu.

Pada umumnya, jadwal waktu salat abadi disusun dengan interpolasi waktu beberapa hari, yaitu antara 3-5 hari, misalnya pada jadwal tertulis tanggal 1-4, 5-8, 9-13, dan seterusnya, dimana waktu Salatnya pada tiap-tiap tanggal interpolasi itu pada jam yang sama. Hal ini dilakukan semata untuk efisiensi ukuran kertas, serta memudahkan dalam pemajangan di Masjid. Selain itu, juga karena rentang waktu Salat pada beberapa hari itu memang sama.

Di kota Medan misalnya, sejak lama telah beredar jadwal waktu salat abadi yang disusun oleh Bustami Ibrahim, dan jadwal ini banyak digunakan oleh masjid-masjid Muhammadiyah di kota Medan. Namun jauh sebelum itu jadwal waktu salat abadi pernah berkembang dan digunakan di masyarakat, yaitu yang disusun oleh Syekh Hasan Maksum (w. 1355/1937), Mufti Kerajaan Deli. Untuk hal ini, Syekh Hasan Maksum menulis 
sebuah buku berjudul Natîjah Abadiyah yang berisi penjelasan waktu-waktu salat sepanjang masa.

Berikut ini adalah perbandingan selisih waktu salat di Sumatera Utara menurut beberapa sumber dengan jadwal waktu salat yang dikeluarkan oleh Observatorium Ilmu Falak Universitas Muhammadiyah Sumatera Utara: ${ }^{14}$

\begin{tabular}{|c|c|c|c|c|c|c|}
\hline \multirow{2}{*}{\multicolumn{2}{|c|}{$\begin{array}{l}\text { Perbandingan/ } \\
\text { Selisih (menit) }\end{array}$}} & \multicolumn{5}{|c|}{ Syekh Hasan Maksum } \\
\hline & & Subuh & Zuhur & Asar & Maghrib & Isya \\
\hline \multirow{4}{*}{$\begin{array}{c}\text { Natijah } \\
\text { Abadiyah }\end{array}$} & Maret & 2-4 Menit & 1-2 menit & 3 Menit & 1-2 Menit & 2 Menit \\
\hline & & & & & & \\
\hline & Juni & 5-6 Menit & 2-3 Menit & 3 Menit & 2 Menit & 2 menit \\
\hline & Desember & 6- 7 menit & 4- 5 menit & 2- 3 menit & 2-3 menit & $1-2$ menit \\
\hline
\end{tabular}

\begin{tabular}{|c|c|c|c|c|c|c|}
\hline \multicolumn{2}{|c|}{$\begin{array}{c}\text { Perbandingan/ } \\
\text { Selisih (menit) }\end{array}$} & \multicolumn{5}{c|}{ H. M. Bustami Ibrahim } \\
\cline { 3 - 7 } \multicolumn{2}{|c|}{} & Subuh & Zuhur & Asar & Maghrib & Isya \\
\hline $\begin{array}{c}\text { Jadual } \\
\text { Abadi H.M. } \\
\text { Bustami } \\
\text { Ibrahim }\end{array}$ & Maret & $1-2$ Menit & $1-2$ menit & $1-2$ Menit & $1-2$ Menit & $1-2$ Menit \\
\cline { 2 - 7 } & Juni & 1 Menit & $1-3$ Menit & $2-5$ Menit & $1-3$ Menit & $4-5$ menit \\
\cline { 2 - 7 } & Desember & $4-5$ menit & $2-4$ menit & $2-4$ menit & $1-2$ menit & $2-4$ menit \\
\hline
\end{tabular}

\begin{tabular}{|c|c|c|c|c|c|c|}
\hline \multicolumn{2}{|c|}{$\begin{array}{c}\text { Perbandingan/ } \\
\text { Selisih (menit) }\end{array}$} & \multicolumn{5}{c|}{ Departemen Agama RI } \\
\cline { 2 - 7 } & Subuh & Zuhur & Asar & Maghrib & Isya \\
\hline $\begin{array}{c}\text { Penentuan } \\
\text { Jadwal } \\
\text { Waktu Salat } \\
\text { Sepanjang } \\
\text { Masa }\end{array}$ & Maret & 0 Menit & $0-1$ menit & $0-1$ Menit & $0-1$ Menit & 0 Menit \\
\cline { 2 - 7 } & Juni & $1-2$ Menit & 1 Menit & 1 Menit & $0-1$ Menit & 0 menit \\
\cline { 2 - 6 } & Desember & 0 menit & 1 menit & 1 menit & $0-1$ menit & $1-2$ menit \\
\hline
\end{tabular}

Di daerah-daerah lain di luar kota Medan jadwal-jadwal waktu salat abadi juga berkembang. Antara lain jadwal waktu salat abadi yang disusun oleh Arius Syekhi, yang berlaku dan beredar di Propinsi Lampung. Selanjutnya jadwal waktu salat 
abadi yang disusun oleh K.H. Noor Ahmad SS untuk Yogyakarta, Jepara, dan Surabaya. Selanjutnya jadwal waktu salat abadi disusun oleh K.H. Slamet Hambali dan K.H. Ahmad Izzuddin untuk kota Semarang dan Sekitarnya. Selain itu, terdapat pula jadwaljadwal waktu salat abadi yang beredar di tengah masyarakat namun tidak diketahui siapa yang menyusun (hâsib)nya.

Pemikiran â sejatinya muncul didasari atas pertimbangan bahwa data gerak harian Matahari sepanjang tahun tidak banyak berubah dari waktu ke waktu. Perubahan harian hanya sedikit sehingga dipandang tidak terlalu berpengaruh, dan dengan demikian dapat dirata-ratakan sepanjang tahun. Peredaran harian matahari yang eksak itu dipandang tidak memiliki perbedaan signifikan dalam penentuan waktu-waktu salat sehingga dapat dijadikan patokan umum dalam menyusun waktu salat secara abadi.

Sejauh ini belum ada penelitian tentang akurasi jadwaljadwal abadi ini. Namun sepanjang jadwal-jadwal itu tidak memiliki perbedaan signifikan dengan jadwal waktu salat modern, maka jadwal waktu salat abadi itu masih sahih digunakan. Namun jika terdapat perbedaan cukup besar (misalnya sampai 5 menit) maka seyogianya jadwal itu agar ditinjau ulang.

Patut dicatat, sebuah jadwal waktu salat dipandang akurat selama dilakukan dengan beberapa faktor. Pertama, jadwal itu dihitung untuk suatu kota berdasarkan koordinat yang akurat dan dengan perhitungan yang akurat pula. Kedua, jadwal itu bukan hasil konversi dari daerah lain. Sebab antara satu daerah dengan daerah lain memiliki perbedaan lintang dan dengan demikian boleh jadi terdapat perbedaan yang cukup signifikan. Sebab, perbedaan angka koordinat akan menyebabkan perbedaan hasil perhitungan. Ketiga, jadwal tersebut selayaknya dikeluarkan oleh satu lembaga terpercaya. Demikian lagi dapat dikeluarkan oleh seseorang (secara pribadi) namun ia memiliki wawasan dan keahlian dalam masalah waktu salat. 


\section{Akurasi Arah Kiblat Masjid Raya al-Mashun}

Kiblat(Arab: al-qiblah) dalam bahasa Arab bermakna 'menghadap' (muqâbalah) dan atau 'arah' (jihah) karena kaum Muslim menghadap ke arahnya ketika salat. ${ }^{15}$ Kata kiblat (al-qiblah) tertera dalam Alquran antara lain diterjemahkan sebagai kiblat (Q.S. al-Baqarah/ 2: 142-145) dan tempat salat (Q.S. Yûnus/10: 87). Dalam bahasa Arab, arah kiblat juga biasa diterjemahkan dengan 'samt alqiblah' (zenit kiblat). Kiblat juga bisa dan biasa diterjemahkan sebagai jarak terpendek ke Kakbah. Kiblat atau Kakbah merupakan tempat dan arah yang dituju kaum Muslim ketika salat. Menghadap kiblat merupakan kemestian (syarat) untuk sah dan berkualitasnya salat yang dilakukan.

Menurut Ulumuddin Siraj (Ketua BKM Masjid Raya alMashun Medan), penentuan arah kiblat Masjid Raya al-Mashun Medan dulunya menggunakan matahari dan kompas sebagai alat untuk menentukan arah kiblatnya. Ia juga mengatakan bahwa dahulu orang yang mengukur arah kiblat masjid ini adalah Syekh Hasan Maksum. ${ }^{16}$

Kontribusi Syekh Hasan Maksum dalam hal arah kiblat adalah fakta akurasi arah kiblat Masjid Raya al-Mashun ini. Dalam penelitian modern terbukti bahwa masjid ini arah kiblatnya sangat akurat. Sejatinya, praktik dan peran Syekh Hasan Maksum terhadap pengkuran arah kiblat masjid ini tidak diketahui persis, sejauh ini belum ditemukan data dan atau catatan tentangnya. Namun melihat dan mengingat kemampuannya dalam bidang ilmu falak secara umum (khususnya tentang waktu salat), maka patut diduga bahwa arah kiblat masjid ini pernah diakurasi oleh Syekh Hasan Maksum. Masjid Raya al-Mashun sendiri adalah masjid idola dan ternama di kota Medan hari ini, tempat dimana Syekh Hasan Maksum dahulu pernah mengabdikan ilmunya kepada masyarakat. 
Dalam pengukuran modern, terbukti bahwa arah kiblat masjid ini arahnya sudah tepat. Akurasi arah kiblat masjid ini antara lain pernah dilakukan oleh Arbisora Angkat dalam penelitian (Skripsi) di Universitas Islam Negeri (UIN) Walisonga Semarang, dengan judul Studi Analisis Penentuan Arah Kiblat Masjid Rayaal-Mashun Medan. Penelitian Arbisora adalah dengan menggunakan kompas dan bayang-bayang matahari (rashdulkiblat) serta menggunakan GPS (Global Positioning System) 60 Garmin. Atas penelitiannya, terbukti bahwa arah kiblat masjid ini masih terbilang akurat.

Melalui rashdul kiblat dan GPS (Global Positioning System) dapat diketahui Masjid Raya al-Mashun Medan memiliki Azimuth Kiblat $292^{\circ} 46^{\prime} 26.6^{\prime \prime}$, dengan Lintang Tempat $03^{\circ} 34.516^{\prime} \mathrm{LU}$ dan Bujur Tempat $98^{\circ} 41.238^{\prime}$ BT. Arbisora melakukan pengukuran selama 3 hari, yaitu pada hari Ahad, 13 Mei 2012, hari Senin, 14 Mei 2012, dan hari Selasa, 15 Mei 2012. ${ }^{17}$

Penentuan arah kiblat berarti menentukan arah di permukaan bumi. Menentukan kiblat berarti menghubungkan tiga buah titik yaitu (1) titik Kakbah, (2) titik suatu lokasi tertentu, dan (3) titik kutub utara. Titik Kakbah dapat dimisalkan dengan titik A (ö = 21 25’ LU dan ë = 39 49’ BT). Titik suatu lokasi (tempat salat) dapat dimisalkan dengan titik B, dan titik kutub utara dapat dimisalkan dengan titik C. Dengan menghubungkan tiga titik ini terbentuklah sebuah segitiga/dengan tiga titik sudutnya. Dalam praktiknya, ada tiga tata cara modern yang sering digunakan dalam pengukuran arah kiblat suatu tempat, yaitu menggunakan ilmu ukur segi tiga bola, memperhitungkan bayang-bayang kiblat, dan memanfaatkan momen matahari melintas di atas Kakbah.

Pertama, ilmu ukur segi tiga bola. Ilmu ukur segi tiga bola (spherical trigonometri, hisâb al-mutsallatsat) adalah ilmu pengukur jarak sudut suatu benda. ${ }^{18}$ Dalam peradaban Islam ilmu ini mulai diperkenalkan oleh al-Khawârizmî (w. 387 H) melalui 
karyanya al-Jabr wa al-Muqâbalah. Pengukuran arah kiblat suatu tempat tidak bisa dilakukan serta merta dengan menarik garis lurus, hal ini mengingat bentuk bumi yang tidak datar namun elips. Dengan bantuan ilmu ukur segi tiga bola inilah bentuk elips bumi dan posisi Kakbah dapat ditentukan di suatu lokasi tertentu.

Kedua, bayang-bayang kiblat. Firman Allah dalam Q.S. alFurqân/25: 45 menyatakan bahwa pada hakikatnya bayang-bayang matahari sebagai petunjuk, diantaranya petunjuk menentukan arah kiblat. Bayang-bayang kiblat terjadi ketika matahari membentuk lingkaran bayangan yang tepat searah (sejalur) dengan Kakbah yaitu ketika deklinasi matahari memotong garis arah kiblat, maka ketika itu bayangan matahari akan membentuk arah kiblat.

Ketiga, momen matahari melintas di atas Kakbah. Fenomena matahari melintas di atas Kakbah atau istiwâ' a'zham atau disebut juga dengan rashd al-qiblah adalah peristiwa astronomis saat posisi matahari berada tepat di atas Kakbah atau ketika matahari berdeklinasi 21를 $25^{\prime}$ yaitu sama dengan Lintang Kakbah (21를'). Fenomena ini terjadi akibat gerak semu tahunan matahari yang hanya terjadi di daerah yang memiliki lintang tidak lebih dari 23,5Ú LU dan 23,5Ú LS. Dalam rentang ini matahari akan menyapu (menyinari) daerah-daerah yang memiliki Lintang

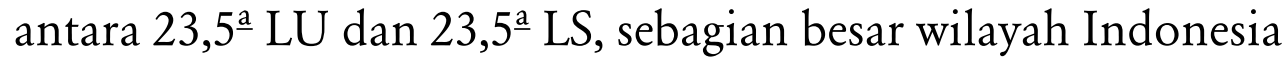
masuk dalam rentang ini dan dimanfaatkan oleh kaum Muslim untuk memastikan arah kiblat secara presisi.

Memastikan arah kiblat melalui fenomena matahari di atas Kakbah (istiwâ' a'zham) adalah cara yang sudah terbukti dan sudah dibuktikan secara berulang-ulang. Cara ini merupakan kaedah alternatif yang akurat tanpa memerlukan perhitungan. Posisi matahari tepat berada di atas Kakbah terjadi apabila deklinasi matahari sama dengan Lintang Kakbah atau Makkah. Ketika itu matahari akan berkulminasi di atas Kakbah dan 
arah terjadinya bayang matahari terhadap suatu benda lurus merupakan arah kiblat. Momen ini di Indonesia terjadi dua kali, yaitu setiap tanggal $27 \mathrm{Mei}$ (tahun Kabisat) atau $28 \mathrm{Mei}$ (tahun Basitat) pukul 16:18 WIB dan tanggal 16 Juli (tahun kabisat) atau 16 Juli (tahun basitat) pukul 16:27 WIB. Sejak dahulu fenomena ini sudah diketahui. Nashîr al-Dîn al-Tûsî misalnya, dalam al-Tazkirah fî̀ 'Ilm al-Hai'ah-nya sudah membahas hal ini. Al-Tûsî mengatakan:

Terdapat ragam cara mengetahui zenit kiblat (samt al-qiblah) -tidak tepat menguraikannya disini-, namun secara mudah dan singkat; matahari akan melalui titik zenit (samt al-ra's) ketika matahari berada pada posisi 8 derajat di rasi Jawzâ' (Gemini) dan 23 derajat di rasi Saramân (Cancer) pada waktu pertengahan hari. Selisih (al-fadhl) antara tengah hari (nishf nahâr) matahari ketika melintas dengan selisih tengah hari (nishf nahâr) di berbagai tempat akan seukuran (qadr altafâwut)dua kali lipat, maka diambillah selisih tersebut. Berikutnya ditetapkan selisih tiap-tiap 15 derajat satu jam, dan satu derajat empat menit, maka hasilnya adalah jarak waktu dari tengah hari. Untuk melihat fenomena pada hari itu adalah pada waktu sebelum tengah hari jika Makkah berada di sebelah timur, atau sesudahnya jika Makkah berada di sebelah barat, maka bayangan itu adalah waktu terjadinya zenit kiblat. ${ }^{19}$

\section{Masjid Raya al-Mashun}

Masjid Raya al-Mashun dibangun pada tahun 1906, dan selesai pada 10 September 1909 M. Saat itu yang berkuasa di Kesultanan Deli adalah Sultan Makmun al-Rasyid Perkasa Alamsyah IX. Seluruh biaya pembangunan masjid yang diperkirakan mencapai satu juta gulden ditanggung sendiri oleh Sultan. Masjid ini merupakan masjid kerajaan. Sebab itu dibangun sangat megah. Ketika itu Sultan berprinsip kemegahan masjid lebih utama 
daripada istananya sendiri. Ada tiga sebutan popular untuk masjid ini yaitu Masjid al-Mashun, Masjid Deli dan Masjid Agung Medan. Seiring perkembangan, kemudian terbentuk sebuah pemukiman baru di sebelah masjid yang disebut kota Maksum, sehingga jamaah Masjid semakin ramai. ${ }^{20}$ Al-Mashun yang berarti dipelihara, sesuai namanya hingga kini masih terpelihara dan terperawat dengan baik. Tidak heran, karena masjid ini di masa silam merupakan masjid negara pada masa jayanya Kesultanan Melayu Deli, yang saat itu masuk dalam wilayah Provinsi Sumatera Utara. ${ }^{21}$

Untuk membangun masjid yang indah dan megah itu, Sultan terpaksa memilih J.A Tingdeman, seorang arsitek bangsa Belanda, mengingat ketika itu belum ada seorang arsitek bangsa pribumi. Oleh Sultan, Tingdeman diberi kepercayaan untuk merancang dan mendekorasi masjid sehingga Masjid Raya alMashun tampak anggun dipandang. Peresmian pemakaiannya bertepatan dengan hari dilaksanakan Salat Jumat yang dihadiri oleh pembesar pembesar kerajaan termasuk Sri Paduka al-Mashun, Tuanku Sultan Amis, Abdul Jalal Rakhmadsyah dari Langkat dan Sultan Sulaiman Alamsyah dari negeri Serdang. Pada masa lalu masjid ini merupakan tempat Salat Jumat satu-satunya di wilayah Kesultanan Deli. Hal ini menunjukkan bahwa Masjid Raya al-Mashun Medan merupakan masjid kesultanan, tetapi tidak terdapat tempat sembahyang khusus untuk Sultan seperti pada umumnya masjid-masjid kesultanan. ${ }^{22}$

\section{Kitab Natîjah Abadiyah}

Buku ini berjudul Natîjah Abadiyah (Natijah Abadi) karya Syekh Hasan Maksum (w. 1355 H/1937 M). Buku ini berisi 40 halaman, diterbitkan oleh Kedai Kitab 27 Medan. Terdiri atas tiga pembahasan singkat yaitu tentang jadwal (tabel) waktu- 
waktu salat, tentang salat istikharah, dan tentang jumlah dan tata cara tolak fidiyah salat.

Pembahasan jadwal (tabel-tabel) waktu salat merupakan inti buku ini seperti terlihat pada judulnya. Tabel-tabel yang disusun Syekh Hasan Maksum secara umum merupakan tabel-tabel waktu menurut waktunya (jam dan menit). Tabel-tabel itu berupa waktu rembang, waktu Zuhur, waktu Asar, waktu Magrib, waktu Isya, waktu Imsak, waktu Subuh, dan waktu Terbit Matahari (Syuruk). Dalam penggunaan tabel-tabelnya, Syekh Hasan Maksum menggunakan nama-nama bulan menurut penanggalan Masehi (Miladiyah) yaitu Januari, Pebruari, Maret, April, Mei, Juni, Juli, Agustus, September, Oktober, Nopember, dan Desember. ${ }^{23}$

Pada bagian awal (mukadimah), Syekh Hasan Maksum menjelaskan tentang tata cara mengetahui waktu rembang, ia mengatakan:

Ketahuilah, bahwa mengetahui waktu rembang itu hendaklah dibuat satu daerah yang rata. Lalu bagian tengah diberi tanda yang panjangnya sepertiga daerah itu. Lalu tandai tempat masuknya bayang-bayang tanda itu dan tempat keluarnya, lalu hubungkan antara keduanya dengan garis lurus (disebut garis Timur dan Barat). Lalu garis lagi pada lintangan garis itu dengan garis yang lurus pula (disebut garis Selatan-Utara), maka letakkan tanda itu di atas garis Selatan-Utara itu. Maka apabila hilang bayang-bayang tanda itu atau bertentangan ia dengan garis Selatan-Utara itu maka itulah waktu rembang dan lihatlah jamnya pada jadwal ini dan betulkanlah jam menurut yang dinyatakan padanya dan waktu-waktu yang lain menurut kepada jam yang dibetulkan ini. ${ }^{24}$

Pada halaman 28, terdapat jadwal untuk mengetahui awal bulan hijriah dengan kemungkinan bersesuaian atau terkemudian dengan rukyat, dan tidak mungkin terdahulu dari rukyat. Pada halaman 30-31 berupa pembahasan tentang anjuran salat istikharah. 
Di sini diuraikan faidah, tata cara, bacaan-bacaan, dan doa salat istikharah. Sedangkan yang terakhir (halaman 3240) berisi penjelasan tentang tata cara dan bacaan tolak fidiyah salat. ${ }^{25}$

\section{Penutup}

Syekh Hasan Maksum adalah tokoh ulama disegani di zamannya, bahkan kepopulerannya (khususnya di Sumatera Utara) sampai hari ini masih terasa. Selain menguasai fikih, akidah, dan tasawuf, Syekh Hasan Maksum juga memiliki telaah dalam bidang ilmu falak. Natîjah Abadiyah tampaknya adalah satu-satunya karya Syekh Hasan Maksum yang berkaitan dengan ilmu Falak. Buku ini berisi penjelasan singkat tentang waktuwaktu salat secara aplikatif dalam bentuk jadwal salat abadi. Buku ini betapa pun sangat ringkas namun memberi pemahaman paripurna tentang arti penting awal dan akhir waktu salat yang termanifestasikan dalam bentuk jadwal waktu salat abadi. Dalam beberapa waktu buku dan jadwal waktu salat (abadi) ini menjadi panduan umat Islam di Sumatera Utara dalam menentukan waktu salat.

Selain itu, Syekh Hasan Maksum juga berperan dalam mengukur dan atau mengakurasikan arah kiblat Masjid Raya al-Mashun. Terbukti dengan penelitian modern arah kiblat masjid ini terbilang akurat. Atas karya dan pemikirannya tentang waktu salat (abadi) dan arah kiblat ini, dapat dinyatakan bahwa Syekh Hasan Maksum berperan dalam historiografi dan peta transmisi perkembangan Ilmu Falak di Nusantara.

\section{Pustaka Acuan}

Al-Dîn al-Qalyûbi, Syihâb. al-Hidâyah min al-Dalâlah fi Ma'rifah al-Waqt wa al-Qiblah min Ghair Âlah. Kairo: Dâr al-Aqshâ, 1991. 
Al-Thûsî, Nashîruddîn. Al-Tazkirah fî 'Ilm al-Hai'ah, ditahkik Abbas Sulaiman. Kuwait: Dâr Sa'ad al-Shabâh, 1993.

Angkat, Arbisora. "Studi Analisis Penentuan Arah Kiblat Masjid Raya al-Mashun.” Medan. Skripsi: 2012.

Butar-Butar, Arwin Juli Rakhmadi. Mengenal Karya-karya Ilmu Falak Nusantara. Yogyakarta: LKiS, 2017.

Butar-Butar, Arwin Juli Rakhmadi. Waktu Salat Menurut Fikih dan Astronomi. Medan: LPPM-UISU, 2016.

Hidayat, Muhammad. "Menelaah Penyebab Perbedaan Hasil Perhitungan Jadwal Waktu Sholat di Sumatera Utara.” Makalah, tidak diterbitkan.

Ilyas, Ahmad Fauzi. "Shaikh Hasan Maksum (1302-1355 H/ 1884-1937 M): Biografi dan Sumbangan Karya Tulisnya di Sumatera Utara Awal Abad 20.” Makalah, tidak diterbitkan.

Ja'far. "Peran Al Jam 'iyatul Washliyah dalam Merevitalisasi Madhhab Shafi'i di Era Kontemporer," dalam Justicia Islamica: Jurnal Kajian Hukum dan Sosial, Vol. 13, No. 1, 2016.

Ja'far. "Respons Dewan Fatwa Al Jam'iyatul Washliyah terhadap Isu Akidah dan Syariah di Era Global,” dalam al-Manahij: Jurnal Kajian Hukum Islam, Vol. 10, No. 1, 2016.

Ja'far. "Tarekat dan Gerakan Sosial Keagamaan Shaykh Hasan Maksum," dalam Teosofi: Jurnal Tasawuf dan Pemikiran Islam, Vol. 5, No. 2, 2015.

Ja'far. Biografi Ketua Umum Pengurus Besar Al Jam'iyatul Washliyah 1930-2015. Medan: Perdana Publishing-CAS, 2015.

Ja'far. Tradisi Intelektual Al Washliyah: Biografi Ulama Kharismatik dan Tradisi Keulamaan. Medan: Perdana Publishing, 2016.

Kamal al-Dîn, Husain. al-Mursyid li al-Tijâhât al-Qiblah wa alMawâqît li al-Shalâh. Arab Saudi: Jâmi'ah al-Imâm Muhammad bin Su'ûd al-Islâmiyyah, 1982. 
Katimin, et al. Sejarah Sosial Kesultanan Deli. Medan: IAIN Sumatera Utara-Puslitbang Lektur dan Khazanah Keagamaan, t.t.

Majelis Ulama Sumatera Utara. Sejarah Ulama-Ulama Terkemuka di Sumatera Utara. Medan: IAIN Sumatera Utara, t.t.

Majma' al-Lugah al-'Arabiyyah. Al-Mu'jam al-Wajîz. al-Hai'ah al-'Âmmah li Syu'ûn al-Mathâbi' al-Amiriyah, Jumhûriyah Mishra al-Arabiyah, Wizârah al-Tarbiyyah wa al-Ta'lîm, 2007.

Maksum, Hasan. Natîjah Abadiyah. Medan: Kedai Kitab 27, t.t.

Mona, Matu. Riwajat Penghidoepan al-Fadhil Toean Sjech Hasan Ma'soem. Medan: Typ Sjarikat Tapanoeli, t.t.

Saragih, Aliman. "Kontribusi Al Jam'iyatul Washliyah terhadap Kemerdekaan Indonesia (1930-1950)," dalam MIQOT:Jurnal Ilmu-ilmu Keislaman, Vol. 40, No. 1, 2016.

Siddik, Dja'far, dan Ja'far, Al-Ittihadiyah: Delapan Dasawarsa Menerangi Nusantara. Medan: Perdana Publishing, 2017.

Suprayitno. "Islamisasi di Sumatera Utara: Studi tentang Batu Nisan di Kota Rantang dan Barus," dalam MIQOT:Jurnal Ilmu-ilmu Keislaman, Vol. 36, No. 1, 2012.

Wajdi, Muhammad Farid. Dâ'irah al-Ma ârif al-Qarn al-'Isyrîn, jilid VII. Beirut: Dâr al-Ma'rifah, 1971.

Zein, Abdul Baqir. Masjid Masjid Bersejarah di Indonesia. Jakarta: Gema Insani Press, 1999. 


\section{Catatan Akhir:}

${ }^{1}$ Suprayitno. "Islamisasi di Sumatera Utara: Studi tentang Batu Nisan di Kota Rantang dan Barus," dalam MIQOT: Jurnal Ilmu-ilmu Keislaman, Vol. 36, No. 1, 2012.

${ }^{2}$ Kajian tentang tokoh ini bisa dilihat dalam Ja'far. "Tarekat dan Gerakan Sosial Keagamaan Shaykh Hasan Maksum," dalam Teosofi: Jurnal Tasawuf dan Pemikiran Islam, Vol. 5, No. 2, 2015.

${ }^{3}$ Matu Mona, Riwajat Penghidoepan al-Fadhil Toean Sjech Hasan Ma'soem (Medan: Typ Sjarikat Tapanoeli, t.t.), h. 7.

${ }^{4}$ Majelis Ulama Sumatera Utara, Sejarah Ulama-Ulama Terkemuka di Sumatera Utara (Medan: IAIN Sumatera Utara, t.t.), h. 121.

${ }^{5}$ Ahmad Fauzi Ilyas, Shaikh Hasan Maksum (1302-1355 H/1884-1937 M): Biografi dan Sumbangan Karya Tulisnya di Sumatera Utara Awal Abad 20 (Makalah, tidak diterbitkan), h. 2.

${ }^{6}$ Bahkan diriwayatkan, jika Syaikh Ahmad Khatib berhalangan untuk mengajar, maka Syaikh Hasan Maksum diamanahkan untuk menggantikan beliau untuk mengajar serta menjawab pelbagai pertanyaan dari murid-muridnya.

${ }^{7}$ Majelis Ulama Sumatera Utara, Sejarah Ulama-Ulama, h. 125.

${ }^{8}$ Tentang organisasi ini bisa dilihat Aliman Saragih, "Kontribusi Al Jam'iyatul Washliyah terhadap Kemerdekaan Indonesia (1930-1950)," dalam MIQOT: Jurnal Ilmu-ilmu Keislaman, Vol. 40, No. 1, 2016; Ja'far, "Peran Al Jam iyatul Washliyah dalam Merevitalisasi Madhhab Shafi'i di Era Kontemporer," dalam Justicia Islamica: Jurnal Kajian Hukum dan Sosial, Vol. 13, No. 1, 2016, h. 1-29; Ja'far, "Respons Dewan Fatwa Al Jam'iyatul Washliyah terhadap Isu Akidah dan Syariah di Era Global," dalam al-Manahij: Jurnal Kajian Hukum Islam, Vol. 10, No. 1, 2016; Ja'far, Biografi Ketua Umum Pengurus Besar Al Jam'iyatul Washliyah 1930-2015 (Medan: Perdana Publishing-CAS, 2015); Ja'far, Tradisi Intelektual Al Washliyah: Biografi Ulama Kharismatik dan Tradisi Keulamaan (Medan: Perdana Publishing, 2016).

${ }^{9}$ Dja'far Siddik dan Ja'far, Al-Ittihadiyah: Delapan Dasawarsa Menerangi Nusantara. Medan: Perdana Publishing, 2017.

${ }^{10}$ Matu Mona, Riwajat Penghidoepan, h. 5-14.

${ }^{11}$ Arwin Juli Rakhmadi Butar-Butar, Waktu Salat Menurut Fikih dan Astronomi (Medan: LPPM-UISU, 2016), h. 68.

${ }^{12}$ Husain Kamal al-Dîn, Al-Mursyid li at-Tijâhât al-Qiblah wa al-Mawâqît li ashShalâh (Arab Saudi: Jâmi’ah al-Imâm Muhammad bin Su'ûd al-Islâmiyyah, 1982), h. 59. ${ }^{13}$ Ibid., h. 68-76.

${ }^{14}$ Muhammad Hidayat, Menelaah Penyebab Perbedaan Hasil Perhitungan Jadwal Waktu Sholat di Sumatera Utara (Makalah, tidak diterbitkan, 2017), h. 14.

${ }^{15}$ Syihâb al-Dîn al-Qalyûbi, al-Hidâyah min al-Dalâlah fi Ma'rifah al-Waqt wa al-Qiblah min Ghair Âlah, Tahkik Abd al-Sattâr Abû Ghuddah (Kairo: Dâr al-Aqshâ, 1991), h. 36. Majma' al-Lugah al-'Arabiyyah, al-Mu 'jam al-Wajîz (al-Hai'ah al-Âmmah 
li Syu'ûn al-Mathâbi' al-Amiriyah, Jumhûriyah Mishra al-'Arabiyah, Wizârah al-Tarbiyyah wa al-Ta'lîm, 1428/2007), h. 489; Muhammad Farid Wajdi, Dâ'irah al-Ma'ârif al-Qarn al-'Isyrîn, jilid VII (Beirut: Dâr al-Ma'rifah, 1971), h. 627.

${ }^{16}$ Arbisora Angkat, "Studi Analisis Penentuan Arah Kiblat Masjid Raya alMashun Medan” (Skripsi, 2012), h. 70-71.

${ }^{17}$ Ibid., h. 72-75.

${ }^{18}$ Ilmu ini tidak hanya berguna dalam menentukan arah kiblat, namun juga berguna dalam perhitungan waktu salat, awal bulan, dan gerhana.

${ }^{19}$ Nashîruddîn al-Thûsî, Al-Tazkirah fî 'Ilm al-Hai'ah, Tahkik Abbas Sulaiman (Kuwait: Dâr Sa’ad ash-Sabâh, 1993), h. 272.

${ }^{20}$ Katimin, et al., Sejarah Sosial Kesultanan Deli (Medan: IAIN Sumatera UtaraPuslitbang Lektur dan Khazanah Keagamaan, t.t.), h. 74.

${ }^{21}$ Abdul Baqir Zein, Masjid Masjid Bersejarah di Indonesia (Jakarta: Gema Insani Press, 1999), h. 25.

${ }^{22}$ Ibid.

${ }^{23}$ Arwin Juli Rakhmadi Butar-Butar, Mengenal Karya-karya Ilmu Falak Nusantara (Yogyakarta: LKiS, 2017), h. 89.

${ }^{24}$ Hasan Maksum, Natîjah Abadiyah (Medan: Kedai Kitab 27, t.t.), h. 3.

${ }^{25}$ Ibid. 